\title{
Effects of stress on reproductive functions in the horse
}

\author{
Christine Aurich ${ }^{7}$ and Jörg E. Aurich ${ }^{2}$ \\ Besamungs- und Embryotransferstation ${ }^{1}$ and Klinik für Geburtshilfe, Gynäkologie und Andrologie ${ }^{2}$, Department für Tierzucht und Reproduktion \\ Veterinärmedizinische Universität Wien, Österreich
}

\begin{abstract}
Summary
Stress-induced release of glucocorticoids may suppress reproductive functions but effects of stress on fertility have been studied only to a limited extent in the horse. Only when stress is prolonged, it is likely that the secretion of gonadotrophins will be suppressed. For acute stress it is unclear whether reproduction will be affected. Conflicting data exist on the effects of exercise on reproductive function in stallions. An increasing number of stallions are entered into equestrian competitions in parallel to their breeding career. Stallions competing regularly do not differ in plasma cortisol concentrations from stallions used for breeding only. In contrast, in stallions taking part only occasionally in competitions cortisol concentrations are elevated. However, competing has no negative effect on semen quality. Mares are transported frequently during the periovulatory period and increases in plasma cortisol concentrations show that transportation is a stressful event. However, it does not affect the oestrous cycle and pregnancy rate. Stress related to management of mares for artificial insemination (Al) increased secretion of cortisol but does not affect reproductive function.
\end{abstract}

Keywords: horse, stress, cortisol, reproduction, fertility, reproduction

\section{Einfluss von Stress auf die Fortpflanzung beim Pferd}

Bei verschiedenen Spezies können die Fortpflanzungsfunktionen durch eine in Verbindung mit Stress vermehrte Freisetzung von Glucocorticoiden unterdrückt werden. Beim Pferd liegen bislang aber nur wenige Studien zur direkten Auswirkung von Stress auf die Fruchtbarkeit vor. Nur im Fall einer dauerhaften Stresseinwirkung ist mit Effekten auf die hypothalamische Gonadotropinfreisetzung zu rechnen. Bei akuten Stressformen ist es weitgehend unklar, ob die Fortpflanzungsfunktionen beeinträchtigt werden. Beim Hengst liegen widersprüchliche Daten über den Einfluß von Training auf die Fruchtbarkeit vor. Der parallele Turniereinsatz von Zuchthengsten ist in den letzten Jahren aber zunehmend populär geworden. Bei Hengsten, die regelmäßig an Turnieren teilnahmen, konnten keine höheren Plasmacortisolkonzentrationen nachgewiesen werden als bei Hengsten, die ausschließlich in der Zucht Verwendung fanden. Allerdings fand man bei Hengsten, die nur unregelmäßig im Turniersport eingesetzt wurden, sehr wohl erhöhte Plasmacortisolkonzentrationen. Ein negativer Einfluss auf die Samenqualität konnte jedoch nicht festgestellt werden. Zuchtstuten werden im Zusammenhang mit der Belegung häufig in der Rosse zum Hengst bzw. der Besamungsstation transportiert. Transport wird vom Pferd als ein Stress wahrgenommen. Allerdings werden Rosseablauf und Trächtigkeitsrate durch Transportstress nicht negativ beeinflusst. Auch das Management von Stuten während der Rosse im Zusammenhang mit der künstlichen Besamung (Transport zur Besamungsstation in Verbindung mit häufigen gynäkologischen Kontrollen) führt zu einer vermehrten Freisetzung von Cortisol, jedoch nicht zu einer Beeinflussung der Fruchtbarkeit.

Schlüsselwörter: Pferd, Stress, Cortisol, Fortpflanzung, Fruchtbarkeit, Reproduktion

\section{Introduction}

Interactions between stress and reproductive functions are numerous and a stress-induced activation of the hypothalamic-pituitary-adrenal axis may reduce fertility. In horses, increased secretion of glucocorticoids is caused by exercise (Gordon et al. 2006), transportation (Baucus et al. 1990a and b), pain (Merl et al. 2000) or social stress (Alexander and Irvine 1998). Glucocorticoids may suppress reproductive functions at the hypothalamic, pituitary, ovarian and also uterine level (reviewed by Kalantaridou et al. 2004). Although stressful events may contribute to low reproductive efficiency in several species, effects of stress on fertility have been studied only to a limited extent in the horse. This paper summarises the mechanisms by which stress affects reproduction in other species and reviews stress and reproductive function in the horse.

\section{Mechanisms of stress induced effects on fertility}

Species differences exist in the response to stress and in the neuroendocrine regulation of reproduction. The universal stress response is an activation of the hypothalamo-pituitaryadrenal axis and this can lead to a suppression of $\mathrm{LH}$ release. Chronic stress results in suppressed gonadotrophin secretion and inhibition of reproduction but, when the effect of stress is transient or acute, the effects are less clear (Tilbrook et al. 2000). In sheep, stress-like levels of cortisol suppress follicular growth and delay the preovulatory LH surge when given during the late luteal and follicular phase of the cycle. Stresslike increments in plasma cortisol apparently interfere with the follicular phase by suppressing the development of high $\mathrm{LH}$ pulses which compromise expression of the preovulatory oestradiol rise and the subsequent $\mathrm{LH}$ surge. The effect of cortisol is temporary and ovulations resume shortly after the end of cortisol infusions. Cortisol also enhances the negative feedback of oestradiol and thus reduces the stimulatory effect of oestradiol on $\mathrm{GnRH}$ receptor expression (Macfarlane et al. 2000, Tilbrook et al. 2000). Also in female cattle, acute stress may prevent the preovulatory LH surge (Stoebel and Moberg 1982) and manipulations such as collection of blood samples and a new environment resulted in a per cycle pregnancy rate as low as $17 \%$ in cows (Mann 2001). Confinement 
suppressed the secretion of $\mathrm{LH}$ in ewes but repetition over several days resulted in acclimatization to the stressor with $\mathrm{LH}$ release no longer affected (Rasmussen and Malven 1983).

The stress-induced decrease in LH release is mediated at the hypothalamic level by several neurotransmitters and neuromodulators such as corticotropin releasing factor (CRF), oxytocin, endorphins, epinephrine, norepinephrine and serotonin (Negro-Vilar et al. 1987). CRF and opioidergic systems are closely associated. In women athletes, strenuous exercise evokes activation of opioidergic and CRF systems and the subsequent inhibition of $\mathrm{GnRH}$ release may lead to amenorrhea (Seifer and Collins 1990). In the rhesus monkey, cortisol has been shown to inhibit GnRH release directly but only when cortisol levels are chronically elevated (Dubey and Plant 1985). Also in female pigs and monkeys, plasma cortisol needs to be high for a prolonged period to affect reproduction. Thus, only when stress is prolonged, it is likely that the secretion of gonadotrophins will be suppressed and reproduction inhibited. For acute stress, the most commonly experienced form of stress, it is unclear whether or how reproduction will be affected (Tilbrook et al. 2000).

\section{Reproductive function in stallions submitted to different stressors}

In horses, exercise is often associated with an increased release of cortisol (Snow and Rose 1981). Conflicting data exist on the effects of exercise and other stressors on reproductive function in stallions. Testosterone concentrations in male race horses assumed to experience stress associated with training were lower than in non-trained controls (Baker et al. 1982). This is in agreement with findings in male human endurance athletes showing high plasma cortisol levels and low testosterone concentrations (Roberts et al. 1993). In humans, changes in sperm concentration and morphology were found after enforced exercise. No inhibitory effects of exercise on semen parameters have been demonstrated in stallions so far.

An increasing number of stallions from sport horse breeds are entered into dressage and show jumping competitions in parallel to their breeding career. In a study from our group, stallions competing regularly, i.e. nearly every week-end did not differ in plasma cortisol concentrations from control stallions used for breeding only. In stallions taking part only occasionally in competitions, plasma cortisol concentrations showed marked fluctuations and were significantly elevated (Lange et al. 1997). Stallions taking part in competitions were not only exposed to the stress of the actual event but also to training at home, transportation to the horse show and a new environment and other horses at the show. The individual effects of the factors could thus not be differentiated. Social stress such as regrouping of horses does affect the adrenal axis of subordinate horses and raises free cortisol concentrations in these animals (Alexander and Irvine 1998). Our findings were recently confirmed by another study in sport horses. Competing in either show jumping or dressage increased plasma cortisol and ACTH concentrations, but in experienced horses, this response was less than in non-experienced younger horses (Cayado et al. 2006), indicating adaptation to the stressor over time. A rapid adaptation of horses has also been found to the stress of loading onto a trailer (Shanahan 2003). Taking part in competitions had no negative effect on semen quality in stallions. In contrast, semen motility and total sperm count at most times during the breeding season were higher in stallions taking part in equestrian competitions than in stallions used for breeding only (see Fig 1; Lange et al. 1997).
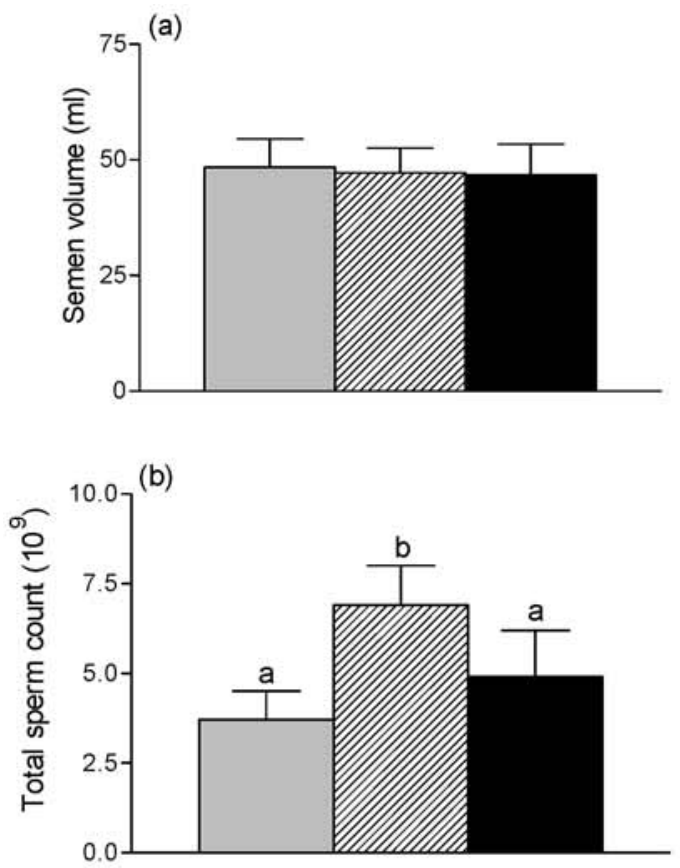

(c)

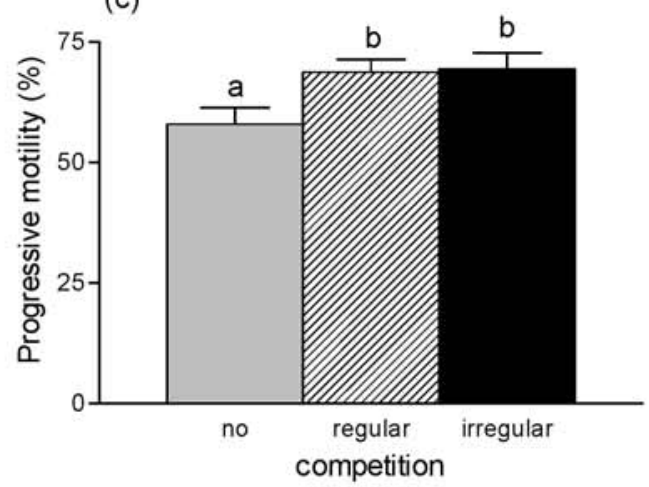

Fig 1 Means of (a) semen volume, (b) total sperm count and (c) progressive motility of ejaculates from breeding stallions that did not compete (grey columns, $\mathrm{n}=10$ ), competed regularly (hatched columns, $n=6$ ) or competed irregularly (black columns, $n=10$ ). Different superscripts indicate significant differences between groups $(p<0.05)$. Modified after Lange et al. (1997).

Mittelwerte von (a) Samenvolumen (ml), (b) Spermiengesamtzahl (Mrd.) und (c) des Anteils vorwärtsbeweglicher Spermien (\%) bei Zuchthengsten, die nicht (grave Säulen, $n=10$ ), regelmäßig (schraffierte Säulen, $n=6$ ) oder unregelmäßig (schwarze Säulen, $n=6$ ) an Pferdeleistungsschaven teilnahmen. ab: signifikante Unterschiede $(p<0,05)$. Modifiziert nach Lange et al. (1997).

\section{Reproductive function in cyclic mares submitted to diffe- rent stressors}

Based on studies in other species, effects of stress on the oestrous cycle in mares have been suggested. It is common practise to transport mares during the periovulatory period to 
the place where the stallion is located. In breeds where artificial insemination (Al) is used on a wide scale, mares are brought to an Al centre for management and detection of the optimal time for insemination. Mare owners often question whether transport shortly before and after ovulation, repeated gynaecological examination and exposure of the mares to a novel environment in the new stable may have negative effects on ovulation and conception.

As shown by increases in plasma cortisol concentrations, transportation (Baucus et al. 1990a and b) and exposure to new horses in a group (Alexander and Irvine 1998) are stressful events for horses. Although cortisol levels were elevated for several hours, no differences in duration of the oestrous cycle, time of ovulation or pregnancy rate between transported mares and non-transported controls were found. Transport had also no effect on $\mathrm{LH}$, oestradiol and progesterone release (Baucus et al. 1990b). As for cyclic mares, road transport of mares at 3 and 5 weeks of pregnancy for 9 hours also caused a transient increase in plasma cortisol levels but did not raise the incidence of early embryonic death. Plasma progesterone concentrations increased during transport and decreased thereafter but not to a level that might endanger pregnancy (Baucus et al. 1990a). The authors suggest that effects of stress on progesterone release may become relevant in mares with marginally low progesterone concentrations before stress, i.e. an already endangered pregnancy (Baucus et al 1990a). Overall, horse mares are apparently less sensitive to transport stress than ruminants. In contrast to the horse, stress associated with

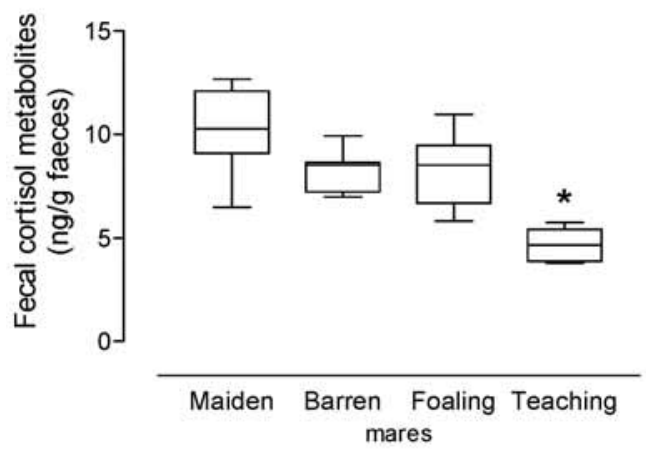

Fig 2 Boxplots of mean of faecal cortisol metabolites ( $\mathrm{ng} / \mathrm{g}$ faeces) from 0 to $72 \mathrm{~h}$ after arrival at the $\mathrm{Al}$ centre in maiden $(\mathrm{n}=16)$, barren $(n=17)$, foaling $(n=12)$ and teaching $(n=5)$ mares (modified after Berghold et al. 2006). * indicates significant difference to all other groups $(\mathrm{p}<0.05)$.

Mittelwerte der fäkalen Cortisolmetaboliten (Boxplots, ng/g Kot) im Zeitraum von 0 bis $72 \mathrm{~h}$ nach Eintreffen auf der Besamungsstation bei Maiden- ( $n=16)$, Güst- $(n=17)$, Fohlen- $(n=12)$ und Übungsstuten $(n=5)$. *: signifikanter Unterschied zu allen anderen Gruppen $(p<0,05)$. Modifiziert nach Berghold et al. (2006).

transportation delayed ovulation, suppressed oestrous behaviour and altered cycle length in ewes (Braden and Moule 1964).

Although the stress caused by transportation does not lead to fertility problems in mares, it is not known whether stress related to the complex management of mares for Al may affect fertility. In many horse breeds, Al has more or less substituted natural breeding. However, the use of this biotechnique requi- res a more intensive management of the mare than natural breeding in order to detect the optimal time for insemination. We have therefore investigated whether management of mares for artificial insemination in an Al centre affects cortisol secretion and reproductive parameters (Berghold et al. 2006). To avoid disturbance of mares by repeated blood
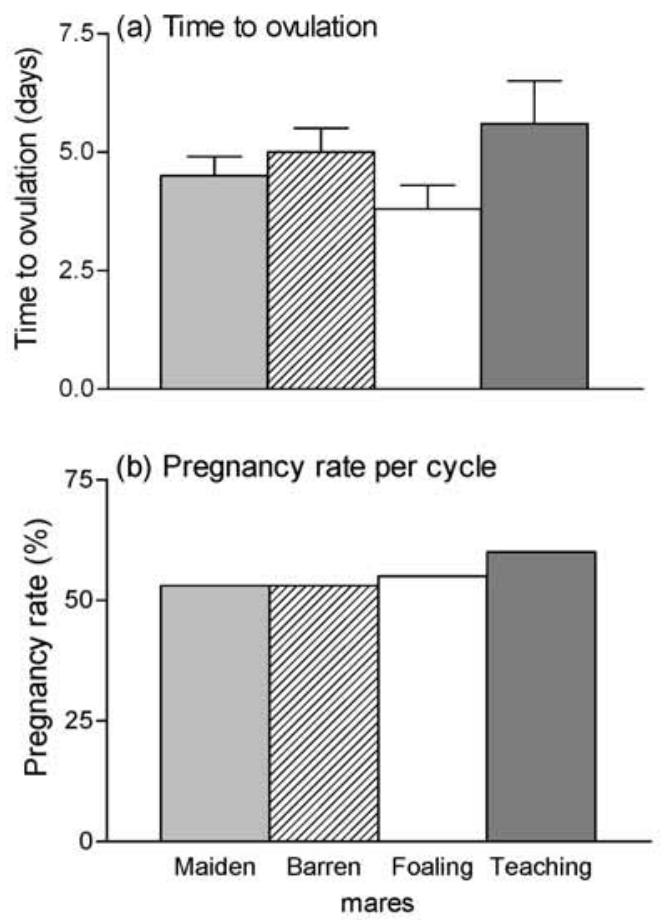

Fig 3 (a) Time from arrival at the Al centre to ovulation (days) and (b) pregnancy rate per cycle (\%) in maiden $(n=16)$, barren $(n=17)$, foaling $(n=12)$ and teaching $(n=5)$ mares (modified after Berghold et al. 2006)

(a) Zeit vom Eintreffen auf der Besamungsstation bis zur Ovulation (Tage) und (b) Trächtigkeitsrate (\%) pro Rosse bei Maiden- $(n=16)$, Güst- $(n=17)$, Fohlen- $(n=12)$ und Übungsstuten $(n=5)$. Keine signifikanten Gruppenunterschiede. Modifizient nach Berghold et al. (2006).

sampling, cortisol was not determined in blood but cortisol metabolites were measured in faeces. Stress related to management of mares for artificial insemination resulted in increased secretion of cortisol. In maiden mares not used to gynaecological examinations the highest cortisol secretion could be detected. Mares transported to an Al centre for artificial insemination are not only exposed to gynaecological examinations but are also stressed by transportation and - in most cases - the loss of social partners in their home stable. These factors contribute to cortisol secretion (Baucus et al. 1990a and b, Alexander and Irvine 1998). In a control group of teaching mares used to repeated restraint and gynaecological examination and not exposed to transportation and loss of social partners secretion of cortisol was lower than in the other groups (see Fig 2). No effect of increased cortisol secretion on reproductive functions could be detected (see Fig 3; Berghold et al. 2006). The horse thus seems to be less sensitive to effects of stress and/or cortisol than sheep and cattle. Even in maiden mares unfamiliar with the management related to $\mathrm{Al}$, the related stress will not result in decreased pregnancy rates. A complete acclimatization to restraint and gynaecological examinations occurred in teaching horses. 


\section{Conclusions}

In domestic ruminants, primates and laboratory animals, stress associated with exercise, management, handling and transport leads to reductions in fertility. Stress-induced disturbances of reproduction are less pronounced in the pig. Horses are exposed to a variety of environmental challenges such as training and exercise, transport, changing companions and new stables. These factors act as potential stressors and increase cortisol release. However, stress-induced cortisol release does not affect reproductive functions, neither in mares, nor in stallions. In addition, horses rapidly get accustomed to potential stressors.

\section{References}

Alexander S. L. and Irvine C. H. G. (1998) The effect of social stress on adrenal axis activity in horses: the importance of monitoring corticosteroid-binding globulin capacity, J Endocrinol 157, 425432

Baker H. W. G., Baker I. D. C., Epstein V. M. and Hudson B. (1982) Effects of stress on steroid hormone levels in racehorses. Austr Vet J 58, 70-71

Baucus K. L., Ralston S. L., Nockels C. F., McKinnon A. O. and Squires E. L. (1990a) Effects of transportation on early embryonic death in mares, J Anim Sci 68, 345-351

Baucus K. L., Squires E. L., Ralston S. L., McKinnon A. O. and Nett T. M. (1990b) Effect of transportation on the estrous cycle and concentrations of hormones in mares, J Anim Sci 68, 419-426

Berghold P., Möstl E. and Aurich C. (2006) Effects of reproductive status and management on cortisol secretion and fertility of oestrous horse mares. Anim Reprod Sci, in press

Braden W. H. and Moule G. R. (1964) Effects of stress on ovarian morphology and estrus cycles in mares. Aust J Agric Sci 15, 937 949

Cayado P., Munoz-Escassi B., Dominguez C., Manley W., Olabarri B., Sanchez de la Muela M., Castejon F., Maranon G. and Vara E. (2006) Hormone response to training and competition in athletic horses. Equine Vet J Suppl 36, 274-278

Dubey A. K. and Plant T. M. (1985) A suppression of gonadotropin secretion by cortisol in castrated male rhesus monkeys (Macaca mulatta) mediated by interruption of hypothalamic gonadotropinreleasing hormone release. Biol Reprod 33, 423-431

Gordon M. E., McKeever K. H., Betros C. L. and Filho H. C. M. (2006) Exercise-induced alterations in plasma concentrations of ghrelin, adiponectin, leptin, glucose, insulin, and cortisol in horses. Vet J. (in press)
Kalantaridou S. N., Makrigiannakis A., Zoumakis E. and Chrousos G. P. (2004) Stress and the female reproductive system, J Reprod Immunol 62, 61-68

Lange J., Matheja S., Klug E., Aurich C. and Aurich J. E. (1997) Influence of training and competition on the endocrine regulation of testicular function and semen parameters in stallions, Reprod Domest Anim 31, 297-302

Macfarlane M. S., Breen K. M., Sakurai H., Adams B. H. and Adams T. E. (2000) Effect of duration of infusion of stress-like concentrations of cortisol on follicular development and the preovulatory surge of LH in sheep, Anim Reprod Sci 63, 167-175

Mann G. E. (2001) Pregnancy rates during experimentation in dairy cows, Vet J 161, 301-305

Merl S., Scherzer S., Palme R. and Möstl E. (2000) Pain causes increased concentrations of glucocorticoid metabolites in horse feces. J Equine Sci 20, 586-590

Negro-Vilar A., Johnston C., Spinedi E., Valenca M. and Lopez F. (1987) Physiological role of peptides and amines on the regulation of ACTH secretion. Ann NY Acad Sci 512, 28-236

Rasmussen D. D. and Malven P. V. (1983) Effects of confinement stress on episodic secretion of LH in ovariectomized sheep. Neuroendocrinology 36, 392-396

Roberts A. C., McClure R. D., Weiner R. I. and Brooks G. A. (1993) Overtraining and male reproductive status. Fertil Steril 60, 686692

Seifer D. B. and Collins R. L. (1990) Current concepts of B-endorphin physiology in female reproductive dysfunction. Fertil Steril 54, 757-771

Shanahan S. (2003) Trailor loading stress in horses: behavioral and physiological effects of nonaversive training. J Appl Anim Welf Sci 6, 263-274

Snow D. H. and Rose R. J. (1981) Hormonal changes associated with long distance exercise. Equine Vet J 13, 195-197

Stoebel D. P. and Moberg G. B. (1982) Effect of adrenocorticotropin and cortisol on luteinizing hormone surge and estrous behavior of cows. J Dairy Sci 65, 1016-1024

Tilbrook A. J., Turner A. I. and Clarke I. J. (2000) Effects of stress on reproduction in non-rodent mammals: the role of glucocorticoids and sex differences, Rev Reprod 5, 105-113

Prof. Dr. Christine Aurich

Centre for Artificial Insemination and Embryo Transfer

Department of Animal Breeding and Reproduction

University for Veterinary Sciences

Veterinärplatz 1

A-1210Vienna

christine.aurich@vu-wien.ac.at

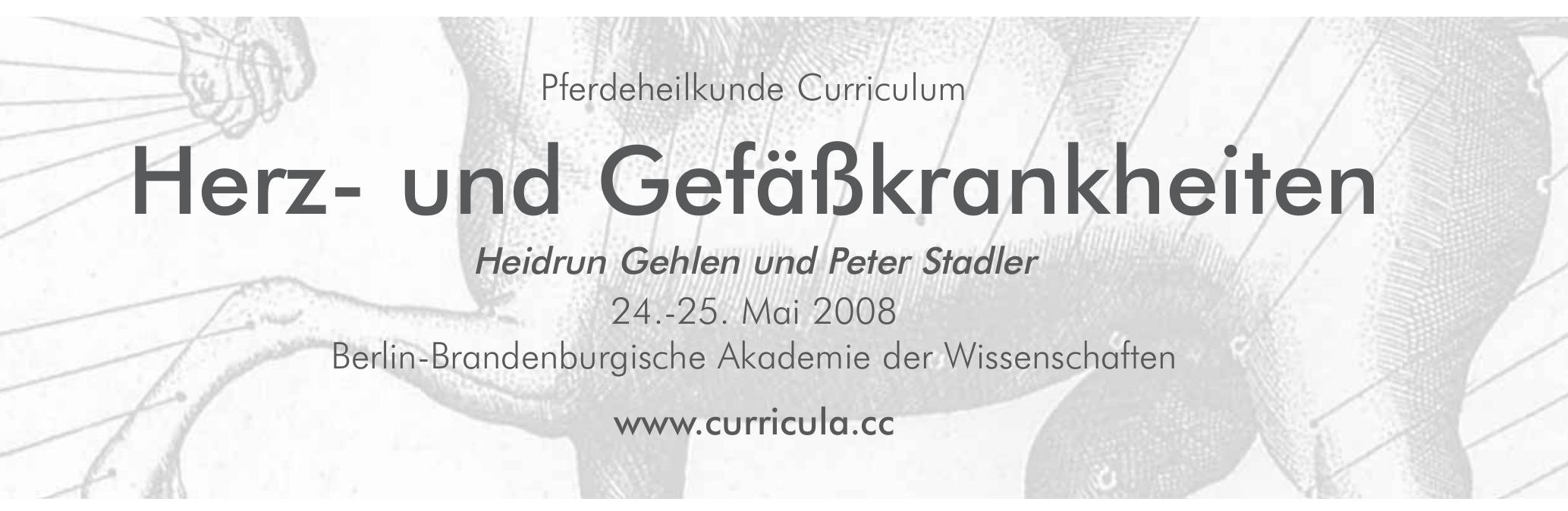

